Proceedings of the 2018 International Scientific Conference 'Economic Sciences for Agribusiness and Rural Economy' No 1, Warsaw, 7-8 June 2018, pp. 92-97

ISBN 978-83-7583-802-2

DOI: 10.22630/ESARE.2018.1.12

\title{
TOWARDS SUSTAINABLE AQUACULTURE IN POLAND
}

\author{
Konrad Turkowski, $\mathrm{PhD}^{1}$ \\ Faculty of Economics, University of Warmia and Mazury in Olsztyn
}

\begin{abstract}
In the late 1980s, inland aquaculture in Poland produced about 20 and 4 thousand tonnes of carp and trout, respectively. In 2016, the total volume of the sector's production increased to over 35 thousand tonnes, including 18 and 16 thousand tonnes of the two species and above 1 thousand tonnes of another fish. This constitutes $94 \%$ of total catches of inland fish and about $15 \%$ including sea fishing. Globally, roughly $50 \%$ of seafood supply is produced by aquaculture, and farmed fish production exceeds that of farmed beef. The EU's Blue Growth Strategy identifies aquaculture as a sector which could boost economic growth across Europe. The key challenges in the Polish aquaculture sector is significant production growth to 49 thousand tonnes by 2020 and increasing its competitiveness by using resources more effectively, supporting the market by building distribution chains, improving the quality of products and marketing, as well as increasing contribution to environmental protection.
\end{abstract}

Keywords: aquaculture, adaptation, sustainability

JEL code: Q22

\section{INTRODUCTION}

The FAO (2018) defines aquaculture as 'the farming of aquatic organisms: fish, molluscs, crustaceans, aquatic plants, crocodiles, alligators, turtles, and amphibians. Farming implies some form of intervention in the rearing process to enhance production, such as regular stocking, feeding, protection from predators, etc. Farming also implies individual or corporate ownership of the stock being cultivated'.

World aquaculture already produces roughly $50 \%$ of the global seafood supply, and farmed fish production exceeds that of farmed beef (Mair, Hobday and Macleod, 2016). With capture fishery production remaining relatively static since the late $1980 \mathrm{~s}$, aquaculture has been responsible for the impressive growth in the supply of fish for human consumption (FAO, 2016).

The EU's Blue Growth Strategy identifies aquaculture as a sector which could boost economic growth across Europe and bring social benefits through new jobs (Science for Environment Policy, 2015). Modern aquaculture growth is not just a matter of new technology. Aquaculture has to be sustainable. It means that it has to be ecologically sound, economically viable and socially acceptable. It involves both the short-run interest of farmers and the long-run interest of society and the environment as a whole.

This article presents the successful adaptation of Polish aquaculture from a centrally controlled one to a modern sustainable market economy.

${ }^{1}$ Corresponding author: Oczapowskiego 4, Olsztyn, Poland, kontur@uwm.edu.pl, +4889 5234332 


\section{MATERIALS AND METHODS}

The paper is mainly based on volume and value data collected by Eurostat, EUMOFA (European Market Observatory for Fisheries and Aquaculture Products), FAO, and FEAP (Federation of European Aquaculture Producers). Important sources of information were strategies for the development of aquaculture in Poland and in the EU: Trout Strategy (2013), Aquaculture Strategy (Ministerstwo Rolnictwa i Rozwoju Wsi, 2015), and Strategy of European Aquaculture (2002).

\section{AQUACULTURE IN POLAND}

Polish aquaculture has a long history, with the first records of activity from around the 11th-12th century. The oldest carp ponds are located in the territories of Zator, Milicz, Cieszyn and Pszczyna (Guziur, 2018). Despite the fact that these ponds are at least 500 years old, they are still functional.

Today, aquaculture in Poland mainly consist of land-based freshwater fish farms. In 2014, there were 1,242 aquaculture farms and their number increased by $47 \%$ compared to 2013 . The sector was dominated by small enterprises with less than 5 employees. $70 \%$ of Polish farms had less than 5 employees, $18 \%$ had 6-10 employees and $12 \%$ more than 10 employees, which means that aquaculture farms were mainly managed by micro and small family enterprises or small and medium companies. The total number of persons employed in the Polish aquaculture sector was 7,664 and this number increased by $43 \%$ compared to 2013 (Nielsen, Guillen and Carvalhoet, 2016). In 2016, total national aquaculture production reached 35,452 tonnes - a $6 \%$ increase compared to 2015 (Fig. 1).

The total value of production was above EUR 91.4 million and there was also an increase of almost $6 \%$. The total volume increased by $5 \%$, whereas the total value increased by only $0.1 \%$ compared to the average between 2011-2015 (Fig. 2).

There are two main sections of Polish aquaculture: extensive carp farming in earth ponds and intensive trout farming in different productive facilities.

The biggest section is carp farming. In 2016, common carp stood for $53 \%$ of the total volume of production and for $46 \%$ of the whole total value of aquaculture production. The volume of annual production of common carp increased to 18.7 thousand tonnes (about 7\%) with a value of EUR 42 million (about $9 \%$ ). Carp can be farmed in a variety of technical and water conditions, in small pools located in home gardens as well as large commercial ponds ranging in size from a few to a few hundred hectares. Carp farms

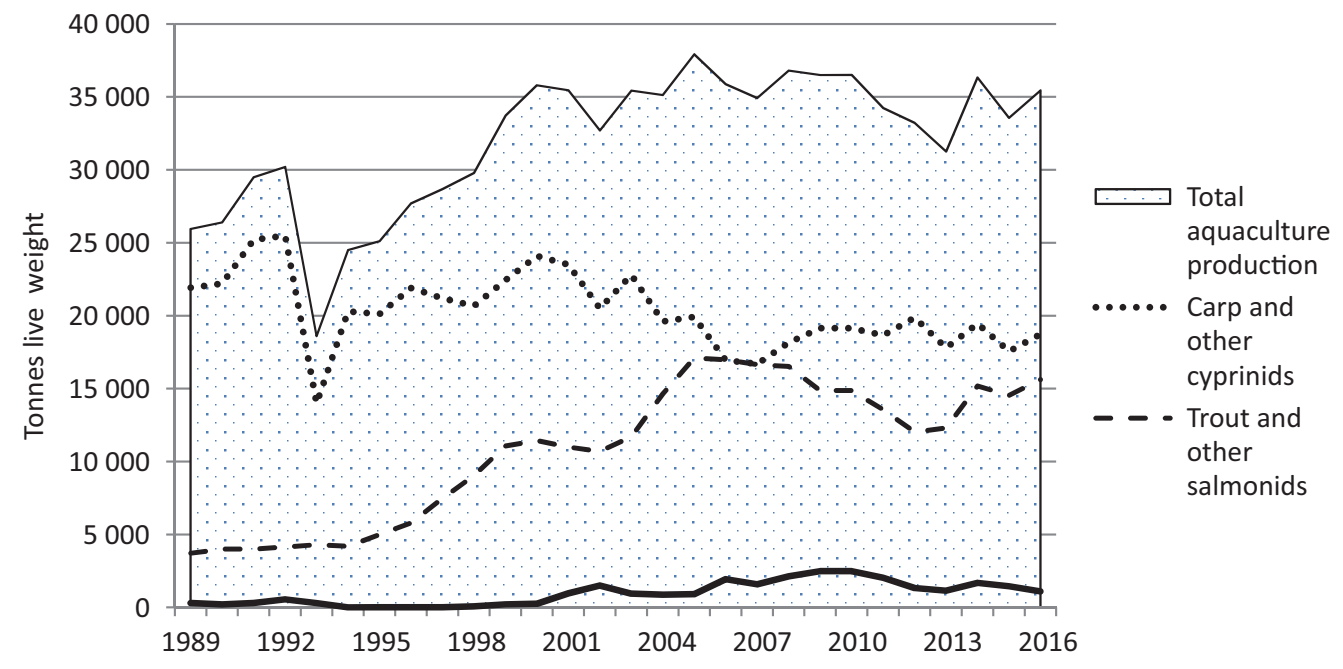

Figure 1. Volume of Polish aquaculture production in the period 1989-2016

Source: developed from Eurostat database. 
are widespread all over the country, but the largest facilities are located in central and southern Poland where climatic conditions are warmer, and thus more advantageous.

Total earth pond useable area of production for carp is about 70 thousand ha, the largest in Europe (Turkowski and Lirski, 2010). Rearing carp usually employs mixed species stock (polycultures). The contribution of other cyprinids in the final production of carp amounted to $10 \%$, and other freshwater species additionally constituted 2\% (Eurostat database). Together, this amounts to about $12 \%$ of other fish species (Ministerstwo Rolnictwa i Rozwoju Wsi, 2015).

The next big section is harvesting rainbow trout (including other salmonids it amounted to about $12 \%$ ), which contributed $44 \%$ of total volume of production and almost $50 \%$ of total value of aquaculture production in 2016 (Figs. 1 and 2). The annual output of rainbow trout increased to 15.5 thousand tonnes (about 7\%) (Fig. 1). On the other hand, the total value of production was EUR 45.2 million, which corresponds to an increase of $8 \%$ (Fig. 2).

Compared to carp, rainbow trout farming is a relatively new industry in the country, having just started in the 20th century. The active development of trout farming started at the end of 1990s, and production has been stagnating over the past few years. Trout production is carried out in intensive fish production facilities (mostly in concrete ponds, so-called raceways) that are supplied with water from rivers or other running sources. Trout farms are located in the north, on the Baltic Sea coast, and in southern Poland in the Carpathian foothills in rich terrain with clear, cool waters. It is estimated that approximately 800 tonnes of salmonids were produced in recirculating aquaculture systems (RAS) (Ministerstwo Rolnictwa i Rozwoju Wsi, 2015). This new technique has also been introduced to the production of such species as sturgeon, barramundi, catfish, wels catfish, pikeperch or eel. They constitute $3 \%$ of turnover in aquaculture and have $5 \%$ share in production volume (Figs. 1 and 2).

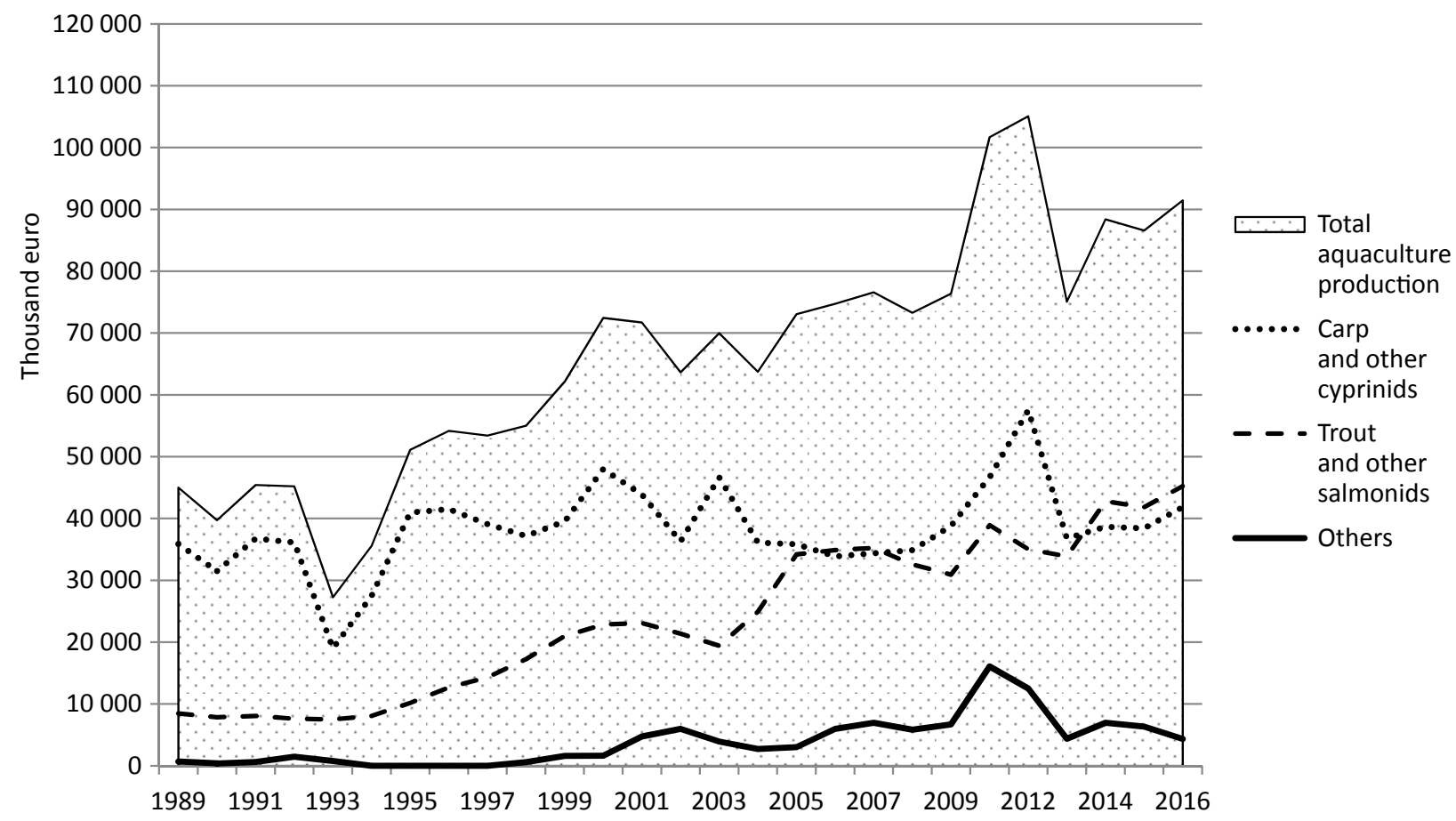

Figure 2. Value of Polish aquaculture production in the period 1989-2016

Source: developed from Eurostat database. 


\section{DEVELOPMENT OF POLISH AQUACULTURE}

In centrally planned economics after World War II, big fish farms belonged to the State. During that period, major technical development started because government financed all investment. It was a period in which rainbow trout culture developed in Poland thanks to new methods of intensive production and efficient controls of spawning time. The basic principles of fishery management, at that time, was so called rational management, based on environmental sustainable intervention, resulting in higher production of better quality fish, achieved at minimal cost ensuring continuity of fish exploitation (Szczerbowski, 1995). There were no problems with fish marketing because the market, at that time, accepted any quantity of fish on offer.

After the political changes in the early 1990s, privatization of state farms began. New private enterprises or private tenets of fish farms were constrained by limited financial resources, increasingly stringent environmental and tax regulations and weaknesses in marketing. In the first years of transition, there was a major decrease in aquaculture production as a result of political and economic changes and a consequent lack of experience in operations under market conditions. In 1993, total aquaculture production fell to the lowest point of 18.6 thousand tonnes and a value of EUR 27.3 million (Figs. 1 and 2). But soon a gradual increase occurred and eventually production was higher than in the eighties. In the late 1980s, inland aquaculture in Poland produced about 20 thousand tonnes of carp and 4 thousand tonnes of trout. In 2016 , the total volume of the sector increased to over 35 thousand tonnes, including 18 and 16 thousand tonnes of the two groups of species and above 1 thousand tonnes of other fish (Fig. 1). This is $94 \%$ of total commercial catches of inland fish and about $15 \%$ including sea fishing (Hryszko, 2017; GUS, 2018).

This success of Polish aquaculture would have been impossible without gradual adaptation to a market economy, new legal regulations and environmental requirements that are important components of a sustainable aquaculture system (Fig. 3).

The two main sections of Polish aquaculture are quite different. Carp farming has positive ecologi- cal impacts (Turkowski and Lirski, 2011) but there is problem with its economic viability. The profitability of this sector should be increased by an average of $10 \%$ through financial support for income diversification (Ministerstwo Rolnictwa i Rozwoju Wsi, 2015).

Intensive trout farming may have, if not properly handled, a negative impact on the quality of water. Basic adaptation processes were initiated by technological changes in fish nutrition. Since 1992 extruded feed began to replace wet feed. The use of balanced feed resulted in a number of positive consequences (SPRŁ, 2013):

- the quality of fish meat has improved,

- fish has been growing faster,

- health and conditions of fish have improved,

- the level of organic and chemical waste has decreased significantly,

- anticipation and management of production has become easier.

As a result, national production of trout reached 10 thousand tonnes in 2000 (Fig. 1). Next, the increase in production to $12-17$ thousand tonnes, starting in 2004, was the result of other technological developments (SPRŁ, 2013):

- water aeration and oxygenation,

- water full or partial recirculation.

Thanks to the applied solutions, intensive trout farming not only significantly reduces the potential negative impact on the environment but also supports self-cleaning of waters from pollution outside the aquaculture system.

The key challenges in the Polish aquaculture sector is significant production growth to 49 thousand tonnes by 2020; this includes a growth of 20 thousand tonnes from earth extensive ponds and 29 thousand tonnes from intensive fish production facilities (Ministerstwo Rolnictwa i Rozwoju Wsi, 2015). This forecast assumes a wide application of new technologies, such as recirculation aquaculture systems (RAS). These high intensive systems are designed to minimize water consumption, control culture conditions and allow waste streams to be fully managed. They can also provide some degree of biosecurity through measures to isolate the stock from the external environment. EU funds play a significant role in the im- 


\section{SUSTAINABLE AQUACULTURE SYSTEM}

\begin{tabular}{|c|c|}
\hline ENVIRONMENT & SOCIAL and ECONOMIC \\
\hline $\begin{array}{l}\text { Mitigat ion negative impacts of. } \\
\text { organic waste and nutrient pollution } \\
\text { (eutrophication, sedimentation), } \\
\text { chemical waste (pharmaceuticals, } \\
\text { pesticides, antifoulants), } \\
\text { escapees (interbreeding, invasive } \\
\text { alien species), } \\
\text { diseases. }\end{array}$ & $\begin{array}{l}\text { New jobs and business opportunities. } \\
\text { Organize production or marketing group (to } \\
\text { negotiate price and taking the advantage of } \\
\text { larger economic of scale). } \\
\text { Marketing development (developing market } \\
\text { demand, product differentiation, pricing, } \\
\text { shortening the marketing channels, product } \\
\text { promotion). } \\
\text { Risk management. } \\
\text { International competition (capital, technology, } \\
\text { legislation, administration). } \\
\text { Improving financial performance. }\end{array}$ \\
\hline
\end{tabular}

Figure 3. Main components, aspects and problems of the sustainable aquaculture system

Source: own elaboration based on Jeng (2002) and Science for Environmental Policy (2015).

plementation of these modern projects in Poland. In 2012, the largest and most modern fish farm in the country, a closed-circuit water system, was opened in the village of Bońki near Płońsk (Indoor RAS - Poland, 2018). The project was financed with the participation of the European Fisheries Fund (EFF). Another example is salmon fish eco-farm Jurassic Salmon Sp. z o.o. This project was co-financed from public funds of EUR 5.7 million, including EUR 4.2 million from the UE (Jurassic Salmon, 2018).

\section{CONCLUSIONS}

World aquaculture has grown at an impressive rate over past decades. It has helped to produce more food fish, kept the overall price of fish down, and made fish and seafood more accessible to consumers around the world. Current production of Polish aquaculture is about one and a half times higher than before the political and economic transformation in the late eighties. What is especially noticeable is the fourfold increase in the production of trout. Efficient adapta- tion to new market and environmental requirements was possible thanks to timely and effective privatization of fish farms. This made it possible to carry out repairs and modernization. The market economy has forced the efficient use of resources and reasonable investment. According to the national plan for development of sustainable aquaculture production, volume should increase by 53\% in 2020. Freshwater fish farming should maintain extensive carp production and double the intensive production volume. Under the Operational Programme 'Fisheries and the Sea 2014-2020' almost EUR 269 million (twice as big an allocation as in the previous programming period) was planned to support the development of aquaculture production. There is also emphasis on extensive aquaculture providing environmental services.

\section{REFERENCES}

1. Eurostat database. Aquaculture production by species. Retrieved: http://ec.europa.eu/eurostat/web/fisheries/ data/database [Accessed 18.05.2018]. 
2. FAO (2016). The State of World Fisheries and Aquaculture 2016. Contributing to food security and nutrition for all. Rome.

3. FAO (2018). Coordinating Working Party on Fishery Statistics (CWP). Retrieved from: http://www.fao.org/ cwp-on-fishery-statistics/handbook/aquaculture-statistics/en/ [Accessed 18.05.2018].

4. GUS (2018). Statistical Yearbook of Agriculture 2017. Dział Wydawnictw Statystycznych GUS, Warszawa.

5. Guziur, J. (2018). Pozaprodukcyjne i proekologiczne walory stawów karpiowych [Non-productive and proecological values of carp ponds]. UWM, Olsztyn.

6. Hryszko, K. (2017). Rynek ryb, stan i perspektywy [Fish market, state and perspectives]. Analizy Rynkowe, 26. IERiGŻ-BIP, Warszawa.

7. Indoor RAS - Poland. Retrieved from: http://aquamaof. com/case_studies_poland.asp [Accessed 18.05.2018].

8. Jeng, S.Ch. (2002). Technological and Economic Adaptations in Aquaculture Development in Taiwan. Thesis submitted for the degree of Doctor of Philosophy. Institute of Aquaculture, University of Stirling, Stirling FK9 4LA, Scotland, UK.

9. Jurassic Salmon. Retrieved from: http://jurassicsalmon. $\mathrm{pl} /$ en/\#research-project [Accessed 29.05.2018].

10. Mair, G., Hobday, A., Macleod, C. (2016). Sustainable aquaculture is possible, with the right science. The Conversation. Retrieved: https://theconversation.com/ sustainable-aquaculture-is-possible-with-the-right-science-67912 [Accessed 19.05.2018].

11. Ministerstwo Rolnictwa i Rozwoju Wsi (2015). Akwakultura 2020 - plan strategiczny chowu i hodowli ryb w Polsce w latach 2014-2020 [Aquaculture 2020 - strategic plan for fish farming in Poland in the years
2014-2020]. Retrieved form: https://www.minrol.gov. $\mathrm{pl} /$ content/download/49857/274182/version/1/file/pdf [Accessed 19.05.2018].

12. Nielsen, R., Guillen, J., Carvalhoet, N. (2016) Scientific, Technical and Economic Committee for Fisheries (STECF) - Economic Report of the EU Aquaculture Sector (EWG-16-12). Publications Office of the European Union, Luxembourg, pp. 301-310.

13. Science for Environment Policy (2015). Sustainable Aquaculture. Future Brief 11. Brief produced for the European Commission DG Environment by the Science Communication Unit, UWE, Bristol. Retrieved form: http://ec.europa.eu/science-environment-policy [Accessed 19.05.2018].

14. SPRŁ (2013). Strategia Rozwoju Zrównoważonej Akwakultury Intensywnej 2020 [A Strategy for the sustainable development of intensive aquaculture 2020]. Stowarzyszenie Producentów Ryb Łososiowatych SPRŁ, Lębork.

15. Strategy of European Aquaculture (2002). A strategy for the sustainable development of European aquaculture. Commission of the European Communities. Brussels.

16. Szczerbowski, J.A. (ed.). 1995. Inland Fisheries in Poland. IRŚ, Olsztyn.

17. Turkowski, K., Lirski A. (2010). The economics of carp farms in Poland. Acta Ichthyologica et Piscatoria, 40 (2), 137-144.

18. Turkowski, K., Lirski A. (2011). Non-productive function of fish ponds and their possible economic evaluation. In: Lirski, A., Pyć, A. (eds.) Carp culture in Europe: Current status, problems, perspectives. IRŚ, Olsztyn, p. 274. 